\title{
Evaluasi Manajemen Pengelolaan Obat Di Dinas Kesehatan Kabupaten Mesuji Tahun 2019
}

\author{
Evaluation of Drug Management at The Mesuji District Health Office in 2019
}

\author{
Hastin Fitria Cahyani ${ }^{1} *$, Ade Maria Ulfa ${ }^{2}$, Christin Angelina ${ }^{3}$. \\ ${ }^{1}$ Mahasiswa Program Studi Magister Kesehatan Masyarakat Universitas Malahayati, \\ Bandar Lampung Indonesia \\ ${ }^{2}$ Program Studi S1 Farmasi Universitas Malahayati, Bandar Lampung Indonesia \\ ${ }^{3}$ Fakultas Kesehatan Masyarakat Universitas Malahayati, Bandar Lampung Indonesia \\ *Korespondensi penulis: hastincahyani@gmail.com
}

Penyerahan: 09-03-2020, Perbaikan: 23-03-2020, Diterima: 27-04-2020

\begin{abstract}
Effective drug management is needed to ensure the availability of drugs with the right type and amount. The purpose of this study was to determine the management of drug management in the Mesuji District Health Office This type of this research uses a qualitative approach. Data collection by depth interview method. The informants in this study were all staff involved in the management of drugs in the Department of Health, totalling 7 people. The results showed that the management of drug management in the Mesuji District Health Office has not been running optimally, including frequent delays in drug use reports, incomplete recording and reporting, there are still quantities and types of drugs that are not in accordance with Puskesmas requests and there are still expired drugs, and training drug management in Puskesmas has not been implemented. The time of procurement and arrival of the drug has not followed the agreed timeliness. At the time of receipt of the drug there is still a drug that is almost out of date. Storage of drugs carried out in the Pharmacy Warehouse. Spatial planning is not good, there is still a build up of drugs and there are expired drugs. Drug distribution from the Health Service to the Puskesmas is carried out by take it directly to the Pharmacy Warehouse and the supervision and evaluation of drug management in Puskesmas has not been carried out effectively and efficiently.
\end{abstract}

Keywords: Drug Planning, Drug Procurement, Drug Storage, Drug Distribution, Supervision and Evaluation of Drug Management

\section{ABSTRAK}

Pengelolaan obat yang efektif diperlukan untuk menjamin ketersediaan obat dengan jenis dan jumlah yang tepat. Tujuan penelitian ini adalah untuk mengetahui manajemen pengelolaan obat di Dinas Kesehatan Kabupaten Mesuji Jenis penelitian ini menggunakan pendekatan kualitatif. Pengumpulan data dilakukan dengan metode wawancara mendalam. Informan pada penelitian ini adalah seluruh staf yang terlibat pada manajemen pengelolaan obat di Dinas Kesehatan yaitu berjumlah 7 orang. Hasil penelitian menunjukkan bahwa manajemen pengelolaan obat di Dinas Kesehatan Kabupaten Mesuji belum berjalan maksimal, diantaranya sering terjadi keterlambatan dalam laporan pemakaian obat, pencatatan dan pelaporan belum lengkap, masih terdapat jumlah dan jenis obat yang tidak sesuai permintaan Puskesmas dan masih terdapat obat kadaluwarsa, serta pelatihan pengelolaan obat di Puskesmas belum dilaksanakan. Penyimpanan obat dilakukan di Gudang Farmasi. Pengaturan tata ruang kurang baik, masih terdapat penumpukan obat dan terdapat obat kadaluwarsa. Pendistribusian obat dari Dinas Kesehatan ke Puskesmas dilaksanakan dengan cara mengambil langsung ke Gudang Farmasi dan kegiatan supervisi dan evaluasi pengelolaan obat di Puskesmas belum berjalan dengan efektif dan efisien.

Kata kunci: Perencanaan Obat, Pengadaan Obat, Penyimpanan Obat, Pendistribusian Obat, Supervisi dan Evaluasi Pengelolaan Obat. 


\section{PENDAHULUAN}

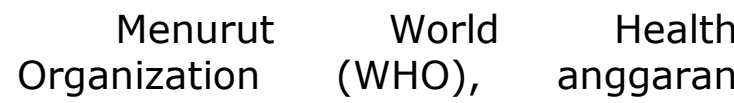
belanja obat merupakan anggaran terbesar dari total dana kesehatan, dan di negara berkembang biaya obat berkisar $24-66 \%$ dari total biaya kesehatan. Belanja obat yang demikian besar tentunya harus dikelola dengan efektif dan efisien. Perencanaan merupakan kegiatan dasar dari pengelolaan obat untuk menentukan kebutuhan obat dan merupakan salah satu fungsi yang menentukan keberhasilan kegiatan selanjutnya di instalasi farmasi yang nantinya akan bermanfaat bagi kelancaran pelayanan kesehatan. Untuk mewujudkan perencanaan tersebut adanya kegiatan pelaksanaan pada tahap ini dilakukan pengadaan obat untuk memenuhi kebutuhan obat yang telah ditetapkan dalam perencanaan. Apabila terjadi kesalahan pada satu tahap akibatnya akan mengacaukan siklus secara keseluruhan yang menimbulkan dampak seperti pemborosan, tidak tersedianya obat, tidak tersalurnya obat, obat rusak, dan lain sebagainya (Sasongko dan Okky, 2016).

Di Indonesia sendiri anggaran obat berkisar 40 persen dari anggaran kesehatan, namun sebagian besar dari populasi mungkin tidak memiliki akses terhadap obat esensial. Dana yang tersedia sangat terbatas dan sering juga dihabiskan untuk obat yang tidak efektif, tidak perlu, atau bahkan berbahaya (Depkes RI, 2002). Anggaran obat untuk pelayanan kesehatan dasar di berbagai daerah berbeda antara satu daerah dengan daerah lainnya, karena adanya perbedaan persepsi serta prioritas pemda tentang kesehatan, walaupun demikian pemerintah pusat tetap bertanggung jawab membantu kabupaten/kota dalam menyediakan obat untuk keperluan bencana dan kekurangan obat (Depkes RI, 2006).

Mengutip dari Direktorat Bina Obat Publik dan Perbekalan Kesehatan Kementerian Kesehatan RI Tahun 2010 tentang materi pelatihan manajemen kefarmasian di instalasi farmasi kabupaten/kota, disebutkan bahwa obat merupakan komponen esensial dari suatu pelayanan kesehatan, selain itu karena obat sudah menjadi kebutuhan di masyarakat, maka persepsi masyarakat tentang hasil dari pelayanan kesehatan adalah menerima obat setelah berkunjung ke sarana kesehatan, yaitu puskesmas, poliklinik, rumah sakit, dokter praktik swasta dan lain-lain.

Pengelolaan obat merupakan suatu rangkaian kegiatan yang menyangkut aspek perencanaan, pengadaan, penyimpanan dan pendistribusian obat, serta penggunaan obat secara rasional. Pengelolaan obat yang efektif terletak pada kebijakan dan kerangka hukum yang membangun dan mendukung komitmen publik untuk pasokan obat esensial dan dipengaruhi oleh isu-isu ekonomi. Tujuan pengelolaan obat adalah tersedianya obat esensial dan dapat diakses oleh seluruh penduduk, menjamin keamanan, khasiat, dan mutu obat yang diproduksi dan pemerataan distribusi, meningkatkan kehadiran obat esensial di fasilitas kesehatan, penggunaan obat rasional oleh masyarakat (Depkes RI, 2010).

Beberapa hal yang masih menjadi permasalahan dalam pengelolaan obat di Indonesia antara lain, masih ada pemerintah daerah yang belum mengalokasikan anggaran untuk obat secara optimal karena kurangnya komitmen pemerintah daerah provinsi dan kabupaten/kota dalam 
mengalokasikan anggaran bagi penyediaan obat dari APBD. Obat yang efektif harus memiliki desain sistem dan manajemen yang baik dengan cara antara lain : menjaga suplai obat tetap konstan, mempertahankan mutu obat yang baik selama proses distribusi, meminimalkan obat yang tidak terpakai karena rusak atau kadaluwarsa dengan perencanaan yang tepat sesuai kebutuhan masing-masing daerah (Kemenkes RI, 2013).

Dinas kesehatan sebagai unsur pemerintah daerah di bidang kesehatan diharapkan dapat memberikan yang terbaik pada masyarakat. Berdasarkan hasil wawancara awal peneliti dengan sebagian pengelola obat di puskesmas terlihat bahwa pengelolaan obat dipuskesmas masih belum terkelola dengan baik, terlihat dari ada beberapa puskesmas tidak mencatat keluar masuknya jumlah obat dengan baik sehingga saat dimintai data tersebut pengelola tidak dapat menunjukkan data yang diminta. Dan didapat pula data perbandingan antara penerimaan obat dengan Rancangan Kebutuhan Obat (RKO) puskesmas rata-rata hanya berkisar 55-60\% saja, hal ini menyebabkan puskesmas sering kali kekurangan obat. Perencanaan kebutuhan obat di dinas kesehatan kabupaten Mesuji dilakukan oleh kepala seksi bidang kefarmasian dengan menggunakan metode konsumsi, dilakukan secara manual dan belum terkomputerisasi. Hal ini dapat menyulitkan petugas dalam menentukan jumlah persediaan. Hasil observasi peneliti di gudang farmasi dinkes kabupaten Mesuji menunjukkan bahwa masih terjadi penumpukan beberapa jenis obat yang sudah cukup lama tidak didistribusikan, karena tidak adanya permintaan obat dari puskesmas.
Hal ini mencerminkan perencanaan kebutuhan obat kurang baik. Masih terdapat penumpukan obat yang kadaluwarsa di gudang farmasi, akibat dari pemulangan obat puskesmas - puskesmas yang belum habis terpakai tetapi sudah kadaluarsa. Hal ini dapat disebabkan karena kurangnya manajemen pengelolaan obat dalam hal mutu dan penyimpanan yang dapat menimbulkan kerugian biaya serta sistem yang masih manual menjadi salah satu penyebab dari kelebihan pemesanan yang akhirnya menimbulkan persediaan yang berlebih.

Dari data yang didapat dari dinas kesehatan propinsi bahwa data perkapita obat di kabupaten Mesuji cukup tinggi dengan urutan ke 2 di bandingkan dengan kabupaten lainnya, tetapi pada kenyataannya di puskesmas - pukakesmas masih sering mengalami obat kosong. Pengelolaan logistik sangat ditentukan oleh kegiatan perencanaan, misalnya dalam menentukan barang yang pengadaannya melebihi kebutuhan. $\mathrm{Hal}$ tersebut dapat merusak suatu siklus manajemen logistik secara keseluruhan, sehingga menimbulkan pemborosan dan pembengkakan dalam biaya, akhirnya obat tidak tersalurkan sehingga bisa rusak atau kadaluwarsa meskipun baik pemeliharaannya di gudang (Seto, 2004).

\section{METODE}

Jenis penelitian ini menggunakan pendekatan kualitatif. Penelitian ini telah dilakukan di Dinas Kesehatan Kabupaten Mesuji dengan alasan lokasi ini masih memiliki permasalahan dalam manajemen pengelolaan obat. Objek penelitiannya meliputi Dinas Kesehatan, Gudang Farmasi, Puskesmas Brabasan dan Puskesmas 
Margojadi. Waktu penelitian direncanakan telah dilakukan pada bulan Agustus - Desember 2019. Kegiatan dimulai dari survey awal, penelusuran bahan, pengambilan data hingga penyajian hasil penelitian. Adapun informan kunci pada penelitian ini adalah Kepala Dinas Kesehatan Kabupaten Mesuji, Kepala Bidang Sumber Daya Kesehatan Dinas Kesehatan Kabupaten Mesuji, Kepala Seksi Kefarmasian Dinas Kesehatan Kabupaten Mesuji. Informan utama dalam penelitian ini adalah Staf Kefarmasian Puskesmas Brabasan dan Staf Kefarmasian Puskesmas Margojadi. Triangulasi sumber data yaitu Kepaala Puskesma Brabasan dan Kepala Puskesmas Margojadi. Jenis penelitian kualitatif dengan instrumen utama adalah peneliti sendiri dengan menggunakan alat bantu : wawancara, perekam gambar dan buku catatan. Pengolahan data yang diperoleh adalah dengan menggunakan analisis isi (Content Analysis) dari hasil wawancara mendalam yang kemudian disajikan dalam bentuk narasi. Hasil catatan wawancara lapangan akan disempurnakan penulisannya serta dilengkapi dengan mengkroscek hasil rekaman agar catatan menjadi lengkap. Hal ini dilakukan untuk menjaga keakuratan dan kelengkapan informasi. Setelah itu dalam memudahkan analisis, akan dibuat matriks berdasarkan masing-masing hasil wawancara. Dengan menggunakan teknik analisis isi, berpedoman terhadap transkrip dan matriks dibuat laporan hasil penelitian. Matriks sangat membantu dalam menetapkan kategori jawaban informan. Adapun proses teknik analisis data, yaitu: proses analisis data dimulai dengan menelaah seluruh data yang tersedia dari hasil wawancara, catatan lapangan dan dokumen. Setelah itu, mereduksi data dengan cara membuat rangkuman, memilih hal- hal yang pokok, memfokuskan pada hal-hal yang penting, untuk pencarian tema dan pola data (inti dan proses dari pernyataan informan). Kemudian, interpretasi data hasil reduksi. Setelah data direduksi, maka langkah berikutnya adalah interpretasi data dengan menyajikan data dalam bentuk teks yang bersifat naratif dan penarikan kesimpulan.

\section{HASIL}

\section{Informan Penelitian}

\section{Tabel 4.1. Informan Penelitian}

\begin{tabular}{|c|c|c|c|c|}
\hline No & Nama & JK & Umur & Jabatan \\
\hline 1 & YF & $\mathrm{L}$ & 54 & $\begin{array}{l}\text { Kadis } \\
\text { Kesehatan }\end{array}$ \\
\hline 2 & $\mathrm{KN}$ & L & 38 & $\begin{array}{l}\text { Kabid Sumber } \\
\text { Daya } \\
\text { Kesehatan }\end{array}$ \\
\hline 3 & DN & $P$ & 32 & Kasie Farmasi \\
\hline 4 & TK & $P$ & 45 & $\begin{array}{l}\text { Kapus } \\
\text { Puskesmas } \\
\text { Brabasan }\end{array}$ \\
\hline 5 & TB & L & 53 & $\begin{array}{l}\text { Kapus } \\
\text { Puskesmas } \\
\text { Margojadi }\end{array}$ \\
\hline 6 & LW & $P$ & 35 & $\begin{array}{l}\text { Pengelola } \\
\text { Obat } \\
\text { Puskesmas } \\
\text { Brabasan }\end{array}$ \\
\hline 7 & RS & $P$ & 30 & $\begin{array}{l}\text { Pengelola } \\
\text { Obat } \\
\text { Puskesmas } \\
\text { Margojadi }\end{array}$ \\
\hline
\end{tabular}

Sumber : Data terolah 2019

\section{Perencanaan Obat di Dinas Kesehatan Kabupaten Mesuji}

Berdasarkan hasil wawancara terkait perencanaan obat dengan informan dapat diketahui bahwa tahapan perencanaan obat di Dinas Kesehatan Kabupaten Mesuji diawali dengan pembentukan Tim Perencanaan Obat yang terdiri dari pihak Dinas Kesehatan dan Puskesmas. Tim yang sudah dibentuk akan diusulkan kepada Bupati Mesuji untuk ditetapkan melalui Surat Keputusan Bupati tentang Tim Perencana Obat Kabupaten Mesuji. Perencanaan 
kebutuhan obat dilaksanakan oleh tim perencanaan obat, yang diketuai oleh Kepala Bidang Sumber Daya Kesehatan dan dibantu oleh Kepala Seksi Kefarmasian.

Dari hasil wawancara diketahui bahwa proses perencanaan obat di Dinas Kesehatan dilaksanakan menggunakan metode konsumsi berdasarkan pada obat generik yang tercantum dalam Daftar Obat Esensial Nasional (DOEN) dan Formulariun Nasional (Fornas). Perencanaan kebutuhan obat telah dilaksanakan sesuai dengan tahapan perencanaan antara lain tahap pemilihan obat dan tahap penghitungan obat, selain itu tugas dari tim perencanaan obat Kabupaten Mesuji kurang maksimal disebabkan kurangnya koordinasi tim perencanaan obat dan tidak pernah melakukan pelatihan terhadap petugas pengelolaan obat puskesmas. Sehingga tidak semua jenis obat yang sudah direncanakan dapat diakomodir dan jumlahnya tidak sesuai permintaan.

Konsep yang diperoleh dari hasil wawancara terkait tentang perencanaan kebutuhan obat di Dinas Kesehatan Kabupaten Mesuji adalah pembentukan tim perencanaan obat. Pemilihan kebutuhan obat menggunakan metode konsumsi berdasarkan pada obat generik yang tercantum dalam DOEN dan Fornas. Proses perencanaan kebutuhan obat publik diawali dari data yang disampaikan Puskesmas (LPLPO) ke Dinas Kesehatan yang dijadikan rencana kebutuhan obat, selanjutnya melakukan perhitungan kebutuhan obat dan disesuaikan dengan anggaran yang tersedia.

Dari uraian pernyataan informan tersebut di atas dapat disimpulkan bahwa manajemen perencanaan obat di Dinas Kesehatan Kabupaten Mesuji telah dilaksanakan oleh tim perencanaan obat, namun belum berjalan dengan baik. Pertemuan/Rapat kerja penyusunan kebutuhan obat hanya dilakukan satu kali dalam setahun, kurangnya koordinasi tim perencanaan obat dan tidak pernah melakukan pelatihan terhadap petugas pengelolaan obat puskesmas. Perencanaan kebutuhan obat telah dilaksanakan sesuai dengan tahapan perencanaan, namun tidak semua berjalan dengan baik, diantaranya sering terjadi keterlambatan dalam laporan data pemakaian obat (LPLPO), tidak semua jenis obat dapat diakomodir oleh Dinas Kesehatan dan jumlahnya tidak sesuai permintaan.

Perencanaan merupakan suatu proses kegiatan seleksi obat dan perbekalan kesehatan untuk menentukan jenis dan jumlah obat dalam rangka pemenuhan kebutuhan obat di Puskesmas. Perencanaan kebutuhan obat untuk Dinas Kesehatan Kabupaten/Kabupaten setiap periode dilaksanakan oleh Tim Perencana Obat dan Perbekalan Kesehatan Kabupaten/ Kabupaten. Dalam proses perencanaan kebutuhan obat per tahun, Puskesmas diminta menyediakan data pemakaian obat dengan mengunakan Laporan Pemakaian dan Lembar Permintaan Obat (LPLPO). Selanjutnya Instalasi Farmasi Kabupaten/ Kabupaten yang akan melakukan kompilasi dan analisa terhadap kebutuhan obat Puskesmas di wilayah kerjanya.

Sumber penyediaan obat di Puskemas berasal dari Dinas Kesehatan. Obat yang diperkenankan untuk disediakan di Puskesmas adalah obat esensial yang jenis dan itemnya telah ditetapkan oleh Menteri Kesehatan dengan merujuk pada Daftar Obat Esensial Nasional (DOEN) dan Formulararium Nasional (Fornas). Selain itu, sesuai dengan 
kesepakatan global maupun Keputusan Menteri Kesehatan No. 85 tahun 1989 tentang kewajiban menuliskan resep dan atau menggunakan obat Generik di Pelayanan Kesehatan Milik Pemerintah dan Permenkes RI No. HK. $\quad$ 02.02/MENKES/068/I/2010 tentang kewajiban menggunakan obat Generik di Fasilitas Pelayanan Kesehatan Pemerintah, maka hanya obat generik saja yang diperkenankan tersedia di Puskesmas.

Hal tersebut sesuai dengan Siregar (2004) dalam bukunya menyatakan bahwa pada pelaksanaan pelayanan kefarmasian di rumah sakit, penggunaan obat, pemesanan obat dan pengadaan obat harus sesuai dengan formularium rumah sakit yang ditetapkan oleh Panitia Farmasi Terapi. Kemudian dalam pelaksanaan Jaminan Kesehatan Nasional (JKN), Formularium Nasional yang merupakan daftar obat terpilih yang dibutuhkan dan harus tersedia di fasilitas pelayanan kesehatan sebagai acuan dalam melaksanakan Jaminan Kesahatan Nasional (JKN). Daftar obat tersebut diadakan melalui sistem katalog elektronik (e-catalogue) yang digunakan sebagai acuan dalam pengadaan obat (Kepmenkes No. 312/MENKES/VII/2013).

Setiap

Kabupaten/Kota mempunyai struktur dan kebijakan sendiri dalam pengelolaan obat, sebaiknya pengelola obat Kabupaten/Kota dilaksanakan oleh Unit Pengelola Obat Publik dan Perbekalan Kesehatan (UPOPPK) Kabupaten/Kota atau gudang farmasi agar pengelolaan obat dapat terlaksana dengan baik dan tidak terjadi tumpang tindih pelaksanaan tupoksi antara gudang farmasi dengan bagian perencanaan dan keuangan. Keterbatasan sumber daya manusia berupa tenagafarmasi menjadi faktor kendala dalam pengelolaan obat di kabupaten. Perencanaan kebutuhan obat sebaiknya dilakukan sebelum tahun anggaran berjalan atau pada akhir tahun, dimana sebaiknya proses perencanaan melibatkan kepala puskesmas, kepala UPTD Farmasi dan bagian perencanaan dan keuangan. Waktu pelaksanaan perencanaan di Dinas Kesehatan Kabupaten Mesuji di mulai pada awal trisemester pertama.

\section{Pengadaan Obat di Dinas Kesehatan Kabupaten Mesuji}

Hasil wawancara dengan Kepala Bidang Sumber Daya Kesehatan Kabupaten Mesuji dijelaskan bahwa kedudukan Kepala Bidang Sumber Daya Kesehatan dalam kegiatan pengadaan adalah sebagai Pejabat Pembuat Komitmen (PPK) dengan pihak rekanan. Proses pengadaan obat diawali dengan perencanaan obat yang telah dibuat oleh tim perencana obat. Setelah melalui beberapa seleksi dan evaluasi melalui katalaog elektronik obat, maka PPK membuat daftar obat yang dibutuhkan, dan selanjutnya disampaikan kepada pokja Unit Layanan Pengadaan (ULP) untuk segera membuat paket pembelian obat dalam aplikasi epurchasing berdasarkan daftar pengadaan obat.

Berdasarkan keterangan yang didapat dari Kepala Seksi Kefarmasian Dinas Kesehatan Kabupaten Mesuji dijelaskan bahwa setelah proses pengadaan selanjutnya adalah proses penerimaan obat di Gudang Farmasi Dinas kesehatan Kabupaten Mesuji yang melibatkan tim pemeriksa barang. Namun pada kenyataannya tidak semua obat yang diterima dilakukan 
pemeriksaan pada waktu penerimaan barang disebabkan jumlah barang yang banyak dan beban kerja petugas yang tinggi. Informan menjelaskan salah satu penyebabnya adalah kurangnya jumlah SDM yang melakukan pemeriksaan obat dan alat-alat pendukung yang dibutuhkan dalam pemeriksaan belum tersedia sehingga membutuhkan waktu yang cukup lama untuk memeriksa obat satu persatu.

Berdasarkan telaah hasil wawancara dengan informan di atas maka dapat simpulkan bahwa pelaksanaan pengadaan obat di Dinas Kesehatan Kabupaten Mesuji berdasarkan katalog elektronik (e-cataloque). Namun masih terdapat jenis obat yang tidak dapat dipenuhi oleh rekanan dengan alasan bahwa jenis obat tersebut habis stok sehingga kebutuhan obat di Puskesmas tidak dapat dipenuhi. Pada tahap pemeriksaan juga terdapat masalah seperti tidak dilakukannya pemeriksaan terhadap semua jenis obat yang diterima pada waktu penerimaan barang. Hal ini dapat menimbulkan masalah seperti jenis obat yang dibutuhkan tidak sesuai dengan jenis obat yang dipesan.

Hasil penelitian ini sejalan dengan penelitian Apriyanti, dkk (2011) tentang evaluasi pengadaan dan ketersediaan obat di RSUD Hadji Boejasin Pelaihari menyatakan bahwa ketersediaan obat di RSUD H.Boejasin masih belum baik yang ditunjukkan dari tingkat ketersediaan obat yang belum memenuhi kebutuhan obat pada unit-unit pelayanan sehingga berdampak pada pelayanan kesehatan kepada masyarakat yang berkunjung ke Rumah Sakit.

Obat merupakan pendukung utama untuk hampir semua program kesehatan di unit pelayanan kesehatan. Belanja perbekalan farmasi yang demikian besar tentunya harus dikelola dengan efektif dan efisien, hal ini perlu dilakukan mengingat dana kebutuhan obat di fasilitas kesehatan tidak selalu sesuai dengan kebutuhan. Pengadaan merupakan kegiatan untuk merealisasikan kebutuhan yang telah direncanakan dan disetujui, melalui pembelian dengan penawaran yang kompetitif (tender) merupakan suatu metode penting untuk mencapai keseimbangan yang tepat antara mutu dan harga, apabila ada dua atau lebih pemasok, pejabat pengadaan harus mendasarkan pada kriteria berikut : mutu produk, reputasi produsen, harga, berbagai syarat, ketepatan waktu pengiriman, mutu pelayanan pemasok, dapat dipercaya, kebijakan tentang barang yang dikembalikan, dan pengemasan. Dinas Kesehatan Kabupaten Mesuji harus cermat dan teliti dalam upaya menyusun perencanaan kebutuhan obat publik agar Dana Alokasi Umum (DAU) yang disediakan oleh pemerintah dapat mencukupi penyediaan obat di Puskesmas yang ada di wilayahnya.

\section{Penyimpanan Obat di Dinas Kesehatan Kabupaten Mesuji}

Dari hasil wawancara dengan Kepala Bidang Sumber Daya Kesehatan Kabupaten Mesuji diketahui bahwa obat-obat yang sudah diterima dan diperiksa akan disimpan didalam gudang farmasi Dinas Kesehatan Kabupaten Mesuji. Luas gudang penyimpanan obat adalah $150 \mathrm{~m}^{2}$. Menurut Kepala Bidang Sumber Daya Kesehatan Kabupaten Mesuji bahwa luas gudang penyimpanan di Dinas Kesehatan Kabupaten Mesuji belum cukup untuk menyimpan obat dengan baik.

Menurut keterangan dari Kepala 
Seksi Kefarmasian dan Kepala Gudang Farmasi Dinas Kesehatan Kabupaten Mesuji, bahwa tata susunan penyimpanan obat di Dinas Kesehatan belum seluruhnya mengikuti prinsip FIFO dan FEFO. Masih ada obat-obatan yang diletakkan dilantai dan tidak beraturan termasuk golongan obat keras yang masih tercampur dengan jenis obat lainnya. Demikian halnya dengan pencatatan obat yang kurang aktif dicatatkan didalam kartu stok obat. Menurut informan hal ini disebabkan karena fasilitas penyimpanan digudang obat masih terbatas. Penyebab lainnya yaitu keterbatasan jumlah tenaga untuk melakukan penyimpanan, pemeriksaan dan pencatatan obat dengan baik. Dari pengamatan penulis juga melihat bahwa kondisi gudang farmasi Dinas Kesehatan kurang memadai terlihat dari atap gudang yang bocor dan penyusunan obat yang ada digudang dalam kondisi berantakan.

Sementara tanggapan dari Kepala Puskesmas Brabasan dan Kepala Puskesmas Margojadi yang menyatakan bahwa gudang penyimpanan obat di Puskesmas sudah memadai hanya saja luas gudang yang terlalu sempit sehingga ada gudang lain yang dipakai untuk meletakkan sisa obat yang tidak tertampung oleh gudang pertama. Gudang kedua inilah yang masih kurang memenuhi standar gudang yang baik. Hasil observasi yang dilakukan diketahui bahwa fasilitas penyimpanan obat di Puskesmas Brabasan dan Margojadi sudah memenuhi standar yang baik haambatannya adalah masalah penerangan, dimana ventilasi diruang penyimpanan obat di Puskesmas sangat terbatas. Untuk penerangan di ruang penyimpanan mengandalkan lampu PLN, namun dikeluhkan juga bahwa PLN di $\begin{array}{lrr}\text { Puskesmas } & \text { kadang } & \text { padam } \\ \text { sehingga } & \text { penyimpanan } & \text { obat }\end{array}$ terganggu. Walaupunpun Puskesmas memiliki genset tetapi terkadang kurang diperhatikan isi bahan bakar getset tersebut, sehingga saat diperlukan tidak teredapat bahan bakar. Dari hasil pengamatan langsung diketahui juga bahwa kartu stok obat di gudang penyimpanan belum lengkap dan bahkan masih ada kartu stok yang belum dicatat.

Keterangan dari Petugas Pengelola Obat Puskesmas Brabasan dan Margojadi bahwa proses penyimpanan obat di gudang penyimpanan obat di Puskesmas dilakukan sudah mengikuti tata aturan penyimpanan yang benar, tetapi karena kurang luasnya gudang penyimpanan jadi masih ada obat yang diletakkan di lantai digudang yang lain karena rak penyimpanan tidak cukup. Demikian juga dengan pencatatan kartu stok obat yang tidak rutin dilakukan. Berdasarkan informasi penelitian yang diperoleh tersebut maka penulis menganalisis bahwa pelaksanaan manajemen penyimpanan obat di Gudang Farmasi Dinas Kesehatan Kabupaten Mesuji dan gudang penyimpanan obat di Puskesmas Brabasan dan Margojadi belum memenuhi prosedur penerimaan, pemeriksaan dan penyimpanan obat yang baik. Hal ini dapat menimbulkan masalah yang berdampak kepada masyarakat yang membutuhkan pelayanan kesehatan di Puskesmas.

Penyimpanan obat di Dinas Kesehatan menggunakan prinsip FIFO (First In First Out) yaitu obat yang datang lebih awal harus dikeluarkan lebih dahulu. FEFO (First Expired First Out), yang berarti obat yang lebih awal kadaluarsa harus dikeluarkan leih dahulu. Obat sediaan disusun berdasarkan abjad (alfabetis) atau nomor. Obat rusak atau kadaluarsa dipisahkan dari obat 
lain yang masih baik dan disimpan di luar gudang.

Sementara hasi penelitian Wahyudi (2013) tentang evaluasi terhadap penyimpanan dan distribusi obat di Dinas Kesehatan Kabupaten Rejang Lebong menunjukkan pengelolaan penyimpanan dan distribusi obat di Dinas Kesehatan Kabupaten Rejang lebong belum sesuai dengan persyaratan yang ditetapkan. Kegiatan penyimpanan memegang peranan penting dalam pengelolaan obat publik. Kegiatan ini dapat berjalan dengan baik apabila didukung oleh sarana penyimpanan yang memadai. Sarana yang tidak memadai menyebabkan penataan obat dalam penyimpanan tidak teratur dan tidak mematuhi kaidah penyimpanan obat, sehingga dapat menyebabkan obat rusak atau expired dalam penyimpan.

\section{Pendistribusian Obat di Dinas Kesehatan Kabupaten Mesuji}

Dari hasil wawancara dengan Kepala Dinas Kesehatan Kabupaten Mesuji dijelaskan bahwa proses pendistribusian obat di Dinas Kesehatan Kabupaten Mesuji dilakukan berdasarkan rencana kebutuhan obat dalam satu tahun dengan mempertimbangkan jumlah sisa obat yang belum terpakai dan jumlah obat yang telah terpakai. Pendistribusian obat akan dilakukan apabila usulan obat yang dibutuhkan telah disetujui oleh Kepala Dinas Kesehatan Kabupaten Mesuji.

Dalam hal persetujuan obat dimaksud, Kepala Bidang Sumber Daya Kesehatan Kabupaten Mesuji memberikan penjelasan bahwa obat yang di distribusikan ke Puskesmas adalah obat yang diusulkan dan disampaikan langsung oleh Puskesmas ke Dinas Kesehatan Kabupaten Mesuji berdasarkan perencanaan obat di Puskesmas sebelumnya.

Kemudian Bidang Pelayanan

Kesehatan akan melakukan pengkajian data LPLPO. Hasil dari pengkajian LPLPO Puskesmas tersebut akan dievaluasi kembali untuk menentukan jumlah dan jenis obat yang akan di distribusikan ke Puskesmas. Setiap jenis obat yang di evaluasi terlebih dahulu mempertimbangkan sisa pemakaian obat yang masih ada di Puskesmas.

Sementara hasil wawancara dengan Kepala Puskesmas Brabasan dan Kepala Puskesmas Margojadi menyatakan bahwa pendistribusian obat ke Puskesmas tidak diantar langsung oleh Gudang farmasi Dinas Kesehatan Kabupaten Mesuji, melainkan pihak Puskesmas yang datang langsung menjemput obat yang telah disetujui oleh Kepala Dinas Kesehatan. Penjemputan obat dilakukan oleh Petugas Pengelola obat Puskesmas bersama dengan supir ambulans dalam kurun waktu tiga bulan sekali (triwulan).

Obat yang sudah diterima akan dilakukan pemeriksaan ulang guna memastikan obat yang diterima apakah sudah sesuai atau tidak dengan yang disetujui. Namun tidak semua jenis obat diperiksa karena biasanya obat-obat yang didistribusikan sudah siap di bungkus dengan kertas kardus atau bahan pembungkus lainnya. Kemudian apabila obat sudah sampai di Puskesmas maka seluruh pustu, poskesdes dan polindes akan diberitahu agar mengambil kebutuhan obatnya di Puskesmas.

Pendistribusian obat mencakup kegiatan pengeluaran dan pengiriman obat-obatan yang bermutu, terjamin keabsahannya serta tepat jenis dan jumlah dari gudang obat secara merata dan teratur untuk memenuhi kebutuhan unit-unit pelayanan kesehatan. Berdasarkan hasil wawancara 
dengan informan, diperoleh kesimpulan bahwa obat yang berada di puskesmas nantinya akan didistribusikan ke Pustu, Poskesdes dan Polindes. Penyaluran obat juga dilakukan di bagian sub-sub puskesmas seperti, (UGD), ruang rawat inap, ruang poli umum dan poli gigi (Kemenkes, 2010).

Cara distribusi obat yang baik adalah cara distribusi/penyaluran obat dan/atau bahan obat yang bertujuan memastikan mutu sepanjang jalur distribusi/penyaluran sesuai persyaratan dan tujuan penggunaannya. Prinsip-prinsip Cara distriubsi obat yang baik berlaku untuk aspek pengadaan, penyimpanan, penyaluran termasuk pengembalian obat dan/atau bahan obat dalam rantai distribusi.

Prioritas pendistribusian obat Puskesmas menekankan kepada obat-obat yang esensial atau yang sering digunakan oleh Pustu, poskesdes, dan Bides maupun ke pasien Puskesmas itu sendiri. Untuk obat-obat narkotika atau semacamnya, puskesmas masih belum memberikan kewenangan Pustu, Poskesdes, dan Polindes untuk menyimpan karena untuk menghindari penyalahgunaan.

Dari pembahasan pendistribusian obat di atas maka dapat disimpukan bahwa manajemen pendistibusian obat di Dinas Kesehatan Kabupaten Mesuji telah berjalan dengan baik. Walaupun secara prosedur seharusnya kegiatan pendistribusian obat ke Puskesmas dilakukan oleh Gudang Farmasi Dinas Kesehatan, namun pada kenyataannya pihak Puskesmas yang menjemput obat di Gudang farmasi. Masalah lain adalah pemeriksaan obat tidak dilakukan secara teliti pada saat obat diserah terimakan kepada petugas pengolala obat puskesmas. Hal ini berpotensi akan menimbulkan masalah seperti jumlah obat yang tidak sesuai, fisik obat yang rusak dan kadarluasa.

Dalam menentukan jumlah obat perlu dipertimbangkan pemakaian rata-rata setiap jenis obat, sisa stok obat, pola penyakit, jumlah kunjungan di masing-masing sub unit pelayanan kesehatan dengan menghitung stok optimum setiap jenis obat. Memeriksa mutu dan kadaluarsa obat-obat dan alat bantu kesehatan yang didistribusi ke subunit pelayanan kesehatan perlu di cek mutu dan kadaluarsanya.

\section{Supervisi dan Evaluasi Manajemen Obat di Dinas Kesehatan Kabupaten Mesuji}

Dari hasil wawancara dengan Kepala Dinas Kesehatan Kabupaten Mesuji dijelaskan bahwa pelaksanaan supervisi dan evaluasi pengelolaan obat dilakukan berdasarkan APBD yang sedang berjalan. Karena untuk melakukan kegiatan supervisi dan evaluasi dibutuhkan dana terutama untuk biaya perjalanan dinas pegawai. Kegiatan supervisi dan evaluasi obat di Puskesmas dikoordinir oleh Kepala Bidang Sumber Daya Kesehatan Kabupaten Mesuji.

Berdasarkan penjelasan Kepala Bidang Sumber Daya Kesehatan Kabupaten Mesuji tentang tahapan kegiatan supervisi dan evaluasi pengelolaan obat yaitu diawali dengan tahapan perencanaan jadwal supervisi, berikut tahap persiapan formulir indikator dan LPLPO serta data-data lain yang menyangkut dengan pengelolaan obat. Personil pelaksana kegiatan supervisi dan evaluasi pengelolaan obat berasal dari Bidang Pelayanan Kesehatan. Hasil kegiatan supervisi akan dijadikan sebagai bahan laporan evaluasi kepada Kepala Dinas Kesehatan Kabupaten Mesuji.

Sementara dari hasil wawancara dengan Kepala Puskesmas Brabasan 
dan Kepala Puskesmas Margojadi menjelaskan bahwa kegiatan Supervisi dan evaluasi yang dilakukan oleh Dinas Kesehatan Kabupaten Mesuji masih belum maksimal. Tim supervisi biasanya datang ke puskesmas hanya melakukan wawancara dengan petugas pengelola obat dan Kepala Puskesmas yang dilakukan diruangan Kepala Puskesmas. Sementara untuk pemantauan langsung ke ruang penyimpanan obat termasuk apotik Puskesmas sangat jarang dilakukan. Waktu yang dibutuhkan untuk supervisi tidak terlalu lama, sehingga petugas pengelola obat tidak mempunyai kesempatan untuk bertanya tentang manajemen pengelolaan obat di Puskesmas. Sedangkan hasil tindak lanjut evaluasi kegiatan supervisi pengelolaan obat di Puskesmas tidak diterima oleh Puskesmas.

Dari hasil analisis wawancara tersebut di atas maka penulis menganalisis bahwa kegiatan supervisi dan evaluasi pengelolaan obat di Dinas Kesehatan Kabupaten Mesuji belum berjalan efektif. Koordinasi antara lintas program masih kurang terjalin dengan baik, demikian halnya juga dengan pembinaan pengelolaan obat ditingkat Puskesmas tidak dilakukan akibatnya kualitas pelayanan obat di Puskesmas semakin rendah.

Supervisi yang dilakukan oleh Dinas Kesehatan adalah proses pengamatan secara terencana dari unit yang lebih tinggi terhadap pelaksanaan pengel olaan obat oleh petugas pada unit yang lebih rendah (Puskesmas/Puskesmas

Pembantu/UPT lainnya). Pengamatan diarahkan untuk menjaga agar pekerjaan atau kegiatan yang dilakukan sesuai dengan pedoman yang disepakati bersama. Supervisi ditujukan untuk menjaga agar pekerjaan pengelolaan obat yang dilakukan sesuai dengan pedoman yang berlaku. Evaluasi dilakukan dengan membandingkan suatu kondisi yang diharapkan dengan kondisi yang diamati. Hasil evaluasi dari hasil supervisi dapat langsung dibahas dengan yang bersangkutan sehingga yang bersangkutan dapat mengetahui kondisinya. Dapatkan kesepakatan dan kemudian coba dibahas langkah-langkah apa yang akan dapat dipergunakan untuk membantu yang bersangkutan untuk mencapai hasil yang diinginkan.

\section{KESIMPULAN}

Perencanaan obat di Dinas Kesehatan Kabupaten Mesuji dilaksanakan oleh tim perencanaan obat yang dibentuk melalui Surat Keputusan Bupati Mesuji. Pengadaan obat di Dinas Kesehatan Kabupaten Mesuji berdasarkan Peraturan Presiden No. 4 Tahun 2015 tentang perubahan keempat atas Peraturan Presiden No. 54 Tahun 2010 tentang pengadaan barang dan jasa Pemerintah, namun dalam pelaksanaannya menghadapi beberapa masalah. Penyimpanan obat dilakukan di Gudang Farmasi Dinas Kesehatan Kabupaten Mesuji dan Pengamanan mutu obat belum dilaksanakan dengan baik. Pendistribusian obat di Dinas Kesehatan Kabupaten Mesuji belum berjalan dengan baik. Kegiatan supervisi dan evaluasi pengelolaan obat di Puskesmas belum berjalan dengan efektif dan efisien.

\section{SARAN}

Diharapkan kepada Puskesmas untuk mengidentifikasi kebutuhan obat dengan baik, sehingga obat yang tersedia sesuai dengan kebutuhan. Pihak Puskesmas hendaknya menyerahkan RKO tepat waktu. Diharapkan kepada Dinas 
Kesehatan Kabupaten Mesuji memilih Pedagang Besar Farmasi (PBF) yang mampu menjamin ketersediaan obat sesuai dengan masa kontrak. Dalam hal obat tidak tersedia dalam e-kataloque, dapat melakukan pemesanan obat secara langsung sesuai pedoman peraturan dan ketentuan yang berlaku.

Menyediakan gudang penyimpanan sesuai dengan standar yang berlaku. Melakukan pencatatan, pengamatan mutu obat, masa kadaluarsa obat secara rutin. Serta menyesuaikan waktu kedatangan obat dengan jadwal pendistribusian obat untuk menghindari penumpukan obatobatan.Meningkatkan pendistribusian obat setiap tiga atau enam bulan disesuaikan dengan persediaan di Gudang Farmasi. Menetapkan dan mensosialisasikan jadwal supervisi ke setiap Puskesmas, melakukan pembinaan dan pengawasan secara rutin, melaksanakan supervisi menggunakan indikator pengelolaan obat agar dapat diketahui tingkat kinerja pengelolaan obat di Puskesmas. dan diharapkan kepada tim supervisi dan evaluasi melaporkan hasil supervisi terhadap masalah dan hambatan yang ditemukan.

\section{DAFTAR PUSTAKA}

Depkes RI. 2002. Pedoman Supervisi dan Evaluasi Obat Publik dan Perbekalan Kesehatan. 2nd ed. Ditjen Yanfar dan Alkes. Direktorat Bina Obat dan Perbekalan Kesehatan. Jakarta. 2006. Kepmenkes No. 189/Menkes/SK/III/2006 tentang Kebijakan Obat Nasional. Jakarta. 2010. Materi Pelatihan Manajemen Kefarmasian di Instalasi Farmasi Kabupaten Kota. Direktorat Bina Obat Publik dan Perbekalan
Kesehatan Kementerian Kesehatan RI Tahun 2010. Jakarta.

No. 2010. Permenkes RI

HK.02.02/MENKES/068/I/2010 tentang Kewajban Menggunakan Obat Generik di Fasilitas Pelayanan Kesehatan

Pemerintah. Jakarta.

Dinkes Kabupaten Mesuji 2018. Profil Kesehatan Tahun 2018. Mesuji.

Hasibuan, Malayu SP, (2016). Manajemen Dasar, Pengertian dan masalah, Jakarta : Bumi Aksara

Kemenkes RI. 2016. Permenkes HK. 02.02/Menkes/137/2016

Perubahan Atas Keputusan Menteri Kesehatan No. HK.02.02/Menkes/523/2015 tentang Formularium Nasional. Jakarta.

. 2013. Kepmenkes RI No. 312/MENKES/SK/IX/2013 tentang Daftar Obat Esensial Nasional. Jakarta.

Sasongko, H., \& Octadevi, O. M. (2016). Overview Of Drug Procurement Management Indicators In Sukoharjo Central Java Hospital. JPSCR: Journal of Pharmaceutical Science and Clinical Research, 1(1), 21-28.

Seto. 2004. Manajemen Farmasi. Airlangga University Press: Surabaya.

Terry and Leslie. 2010. (Penerjemah G.A. Ticoalu). Dasar-Dasar Manajemen. Jakarta: Bumi Aksara.

Warman, J., 1997. Manajemen Pergudangan. Jakarta : LPPM. 